Journal of Economics and Behavioral Studies (ISSN: 2220-6140)

Vol. 8, No. 1, pp. 87-103, February 2016

\title{
The Relationship between External Financial Flows and Economic Growth in the Southern African Development Community (SADC): The Role of Institutions
}

\author{
${ }^{1}$ Kapingura Forget Mingiri*, ${ }^{2}$ S.I Ikhide, ${ }^{3} \mathrm{~A}$ Tsegaye \\ 1,3University of Fort Hare, East London Campus, South Africa \\ ${ }^{2}$ University of Stellenbosch Business School, Cape Town, South Africa \\ *fkapingura@ufh.ac.za
}

\begin{abstract}
The study examined the relationship between external financial flows, domestic savings and economic growth in the SADC region for the period from 1980 to 2009 specifically looking at the role played by institutions. The majority of countries in the SADC region are experiencing low levels of savings, which has led to them relying more on external financial flows to bridge the gap between domestic demand for finance and domestic supply. However the relationship between external finance and economic growth is still a contentious issue. Given this, the study has thus examined the link between growth and external finance in the region, specifically focusing on the impact of the different forms of external financial flows on economic growth in the region incorporating the role played by institutions. The empirical results revealed that three types of external financial flows have a significant impact on economic growth in the SADC region except ODA; however when all the different types of external financial flows were interacted with the measure of institutions, they all become significant and more enhanced in explaining economic growth in the region. This supports the hypothesis that good institutions are necessary in promoting economic growth in developing countries. The empirical results also suggest that foreign capital is another channel through which a crisis in developing countries can be transmitted to the SADC region.
\end{abstract}

Keywords: External Financial Flows; Economic Growth; SADC; Panel Model; Institutions

\section{Introduction and Background to the Study}

Generally it is accepted that foreign capital influences the course of the real economy, and this accounts for the popularity of the subject of capital flows in academic and official policy discourse. Several studies (e.g. Papaioannou, 2005; Prasad and Subramanian, 2007; Cali, Massa and Willem, 2008; Obstfeld, 2008; Adams, 2009; Macias and Massa, 2009) documents the pivotal role of private capital flows in promoting economic growth, especially in developing countries. However, the conclusions have been mixed. The available studies on the relationship between external financial flows and economic growth documents that foreign capital flows may impact positively on both the country of origin and recipient countries. A study by Schoenmaker and Wagner (2011) indicates that the presence of external finance in the form of foreign banks in the domestic economy bring about diversification effects. Foreign banks allow domestic firms to have a multiple lending relationships with domestic and foreign banks. In cases in which domestic banks are lendingconstrained, firms will have the option of the foreign banks. In addition to the benefits which come with cross border banking, there are studies which argue that FDI provides benefits that domestic investment does not. FDI inflows are seen as vehicles for the international transfer of technology and knowhow. Borensztein et al. (1998) and Choong et al. (2010) suggest that foreign capital inflows can provide additional capital and augment domestic savings, promoting capital accumulation and increase the growth rate. Also, external financial flows in the form of portfolio investment are thought to help in the modelling of financial markets in developing countries through knowledge spillover and market efficient effects (Choong et al., 2010).

Within the SADC region, the Regional Interactive Strategic plan states that savings and investments are central determinants of the rate and pattern of economic growth in the region. Through increasing domestic savings and using the resources in productive domestic investment, SADC countries will strengthen the region's prospects for accelerated economic growth, poverty eradication and sustainable development. The report shows that between 2008 and 2012, regional Gross National Savings (GNS) fell short of regional Gross Domestic Capital Formation (GDCF). In 2012, the average SADC GDCF was 20.9 percent of GDP against a 
regional GNS of 16.6 percent of GDP, leaving a resource gap of 4.3 percent and among individual countries, there were wide disparities between saving and investment rates, with most countries recording negative resource balances. Given the low savings rates in the region, this suggests that foreign capital can be another source of capital to support the domestic investments and hence achieve economic growth. However a number of studies such as Acemoglu et al. (2001), Djurovic (2012), Driffield and Jones (2013) have stressed that foreign capital flows are effective given that there are good institutions in the recipient country.

Nevertheless, despite the positive effects associated with foreign capital flows, the ECA (2006) report shows that external financial flows may have negative effects on African economies through the "Dutch Disease" effects in which the increase in the flow of capital increases the demand for the domestic currency which will in turn reduce the competitiveness of a country's export industry and make imports cheaper deteriorating the country's external position. In addition, external financial flows may increase the vulnerability of a country which is caused by the high volatility and unpredictability of capital flows. In addition, studies such as Macias and Massa (2009) argue that the 2008 global financial crisis impacted negatively on the volume of external financial flows to developing countries such as those in the SADC region as the source countries focused on their domestic economy. Also the SADC (2009) report indicates that Oversees Development Assistance to the region was on the decline as donor countries budgets were under pressure. This dilemma was further enhanced by a decline in employment levels, real incomes and remittances from developed countries to the region (SADC Report, 2009). The discussion above thus indicates that there are mixed views regarding the impact of external financial flows on economic growth. This becomes important in the case of SADC countries given the low levels of savings in the region also considering the important role of savings towards investment. Thus the study aims to address a number of questions: Firstly, the study explores the relationship between foreign financial flows and economic growth in the SADC region. Secondly the paper seeks to establish the extent to which SADC countries' growth might have been adversely affected by the foreign capital inflow channel given the uncertainty associated with some of its components. Furthermore, the study looks at the growth impact of the different components of external financial flows, given their unique characteristics.

Overview of Macroeconomic Variables and Trends in Financial Flows in the SADC region: Assessing the state of macroeconomic conditions in the region, as indicated in table 2, on average the SADC region's growth have averaged around 5\%. In addition the SADC countries on average have managed to reduce inflation to single digit figures. However government expenditure still surpasses government revenue. In addition public debt is still huge in the region. Another interesting finding is the deficit between investment and savings. From 2008 to 2012 there is a shortfall in that investment surpasses savings. This suggests the importance of external finance to bridge the gap between the two. This is further illustrated in figure 2.

Table 1: SADC Economic Indicators

\begin{tabular}{llllll}
\hline Period & $\mathbf{2 0 0 8}$ & $\mathbf{2 0 0 9}$ & $\mathbf{2 0 1 0}$ & $\mathbf{2 0 1 1}$ & $\mathbf{2 0 1 2}$ \\
\hline Real GDP (\% Growth) & 4.1 & 1.5 & 5.5 & 4.7 & 5.1 \\
Inflation (\%) & 13.1 & 12.3 & 8.4 & 8.3 & 7.9 \\
Government Revenues (\% of GDP) & 30.2 & 29.3 & 29.7 & 29.2 & 29.7 \\
Government Expenditures (\% of GDP) & 30 & 33.4 & 32.8 & 33.5 & 32.7 \\
Overall Fiscal Balance (\% of GDP) & 2.4 & -4.3 & -3.2 & -4.8 & -3.6 \\
General Public Debt (\% of GDP) & 42.9 & 45.8 & 39.1 & 39.2 & 39.5 \\
Total Investment (\% of GDP) & 23.5 & 21.6 & 22.2 & 21.3 & 20.9 \\
National Savings (\% of GDP) & 16.4 & 13.1 & 15.5 & 14.9 & 16.6 \\
Per Capita GDP based on PPP (\% Growth) & 4.1 & -8.1 & 18.9 & 10.3 & 4.2 \\
Volume of Exports (\% of Growth) & 6.7 & -1.7 & 5.7 & 4.8 & 8.5 \\
Volume of Imports (\% Growth) & 12.1 & -2.2 & 6.1 & 2.3 & 4.6 \\
Current Account Deficit (\% of Growth) & - & - & -8.8 & -8.3 & -6.6 \\
\hline
\end{tabular}

Source: SADC Facts and Figures (2013) 
Figure 1: Trends of Savings and Capital Formation in the SADC region

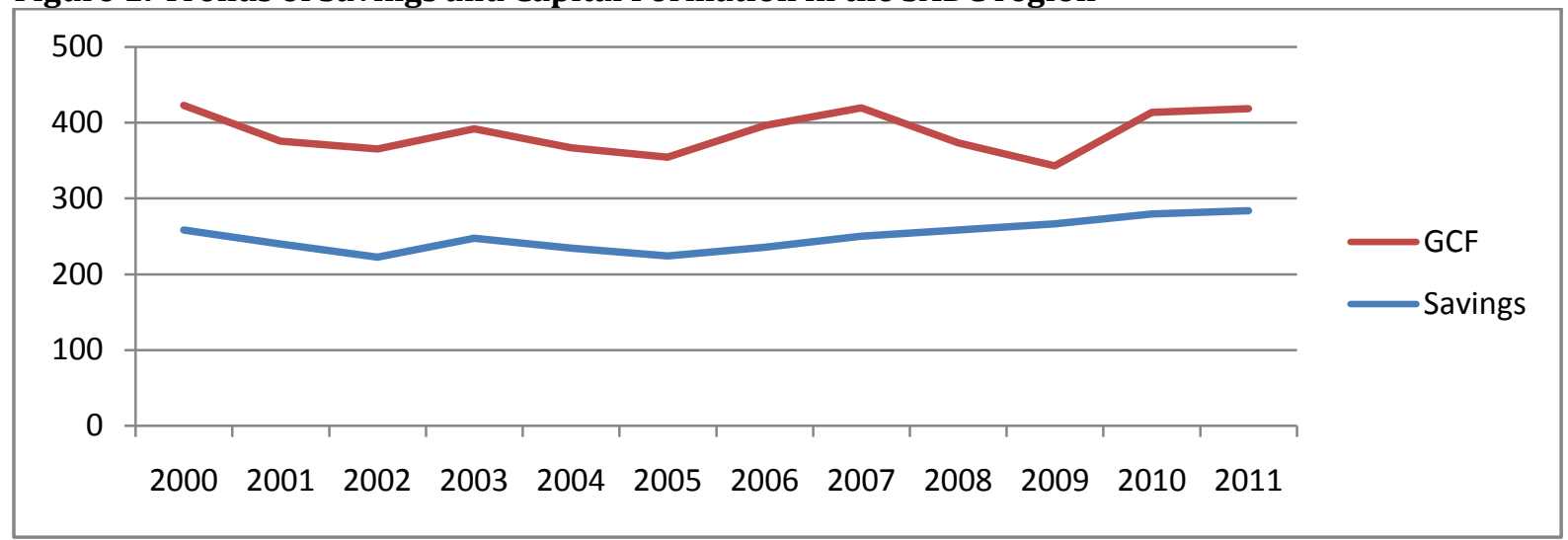

Source: World Bank African Development Indicators

Figure 1 shows the composition of the different capital flows in the SADC region for each country. The four types of external finance analysed are remittances, Foreign Direct Investment, Cross Boarder Bank Flows and Oversees Developemnt Assistance. Figure 2 shows all the four types of foreign capital normalised against GDP. It is clearly evident that ODA, FDI and remittances are the major sources of foreign capital in the SADC region. For countries such as Lesotho, remittances surpasses all other types of capital. However for Mozambique ODA is the major source of foreign capital. The same applies to Malawi and Zambia and Zimbabwe. However countries such as South Africa and Mauritius seem to depent less on these types of foreign capital, on a closer analysis Foreign Portfolio investment which is not icoporated due to lack of data on other coutries seem to be the major component.

\section{Figure 2: Composition of Capital Flow}

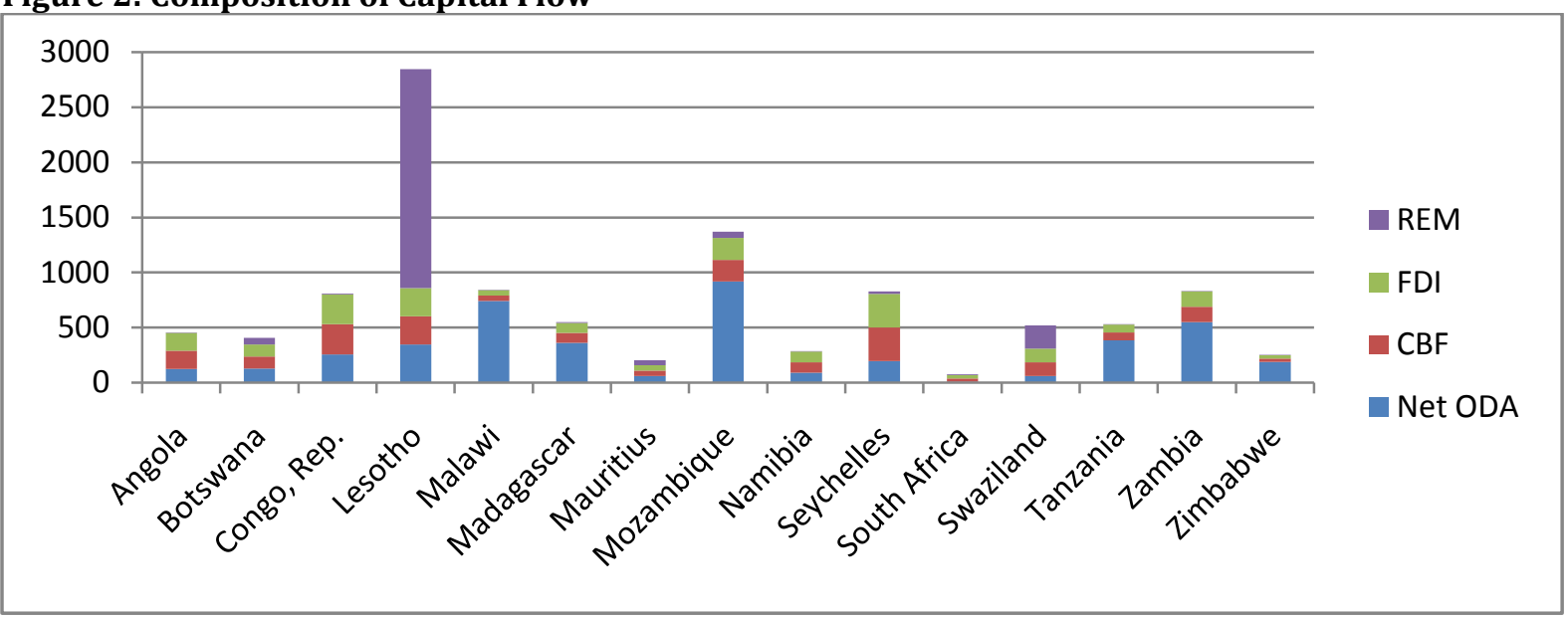

Source: World Development Indicators (2013)

\section{Literature Review}

The majority of studies which have analysed the impact of foreign capital on economic growth have largely relied on the Harold-Domar model which highlights that domestic resources are not sufficient to support investment. Foreign capital therefore bridges the gap between domestic capital supply and demand. It is interesting to note that the major focus of the available studies on the relationship between external financial flows and economic growth have concentrated on establishing the impact of foreign capital on economic growth at macroeconomic level either applying cross-sectional or panel data to a number of countries (Borensztein, De Gregorio and Lee, 1998; Carkovic and Levine, 2002). In addition to those focusing at crosssectional or panel data, there are studies based at micro level data or case studies. These studies include 
Atique, Ahmad \& Azhar (2004), Ayanwale (2007), and Khaliq \& Noy (2007). However, the empirical literature on the impact of foreign capital on economic growth is largely inconclusive. Of noteworthy is that the majority of the cross-sectional and panel data studies, irrespective of the forms of foreign capital, tend to establish a significant positive relationship between the measure of external finance and economic growth (see Borensztein, De Gregorio, and Lee, 1998; Week, 2012). On the other hand the majority of time series country-specific studies have established either a negative relationship or insignificant relationship (see Khaliq and Noy, 2007; Duasa and Kassim, 2009).

Of the available studies, Macias and Massa (2009) analysed the impact of the different forms of capital on economic growth in the Sub-Saharan Africa (SSA) for the period 1980 to 2007. The authors used Bond flows, Cross border bank lending and FDI. Empirical results revealed that both FDI and cross-border bank lending exert a positive and significant impact on economic growth in SSA, whereas portfolio equity flows and bonds flows have been found to have no growth impact. The authors also highlighted that the benefits of crossborder bank flows are still to be realised in Africa due to underdevelopment and fragmentation of the financial markets. This suggests that a well-integrated market may attract more CBF which amongst the other financial and economic spill overs, increase the availability of development finance. The results on FDI are in agreement with Reisen and Soto (2001), Muradzikwa (2002), Toulaboe, Terry and Johansen (2009), Agrawal and Khan (2011), Rachdi and Saidi (2011), Weeks (2012) who shows that an increase in FDI promotes economic growth.

In another separate study, Driffield and Jones (2013) analysed the impact of foreign capital inflows on economic growth of developing countries for the period 1984 to 2007. The authors employed three major measures of foreign capital, remittances, ODA and FDI. Empirical results reveal that both FDI and migrant remittances have a positive impact on growth in developing countries. In addition, the authors argue that the impact of these types of foreign capital is also determined by a better institutional environment in that countries that protect investors and maintain a high level of law and order will experience enhanced growth. However, as regards the impact of aid on economic growth, the authors argue that it is not clear. This suggest that aid is usually "poorly targeted". These results are in line with prior studies such as Griffin (1970), Rana and Dawiling (1990) and Waheed (2004). These studies have suggested that foreign financial flows, especially aid are used for consumption instead of investment in what has come to be known as the fungibility of aid. However this result was found to be contradictory to Ekanayake and Chatrna (2008) study on 85 developing countries covering Asia, Africa, and Latin America and the Caribbean for the period from 1980-2007. The authors established that foreign aid has a positive impact on African countries due to these countries being the largest recipient of foreign aid.

In addition to the studies which have analysed the impact of the different forms of capital on economic growth, there has been a proliferation of studies which have emphasised the importance of institutions in harnessing the positive impact of foreign capital. Based on the work of North (1981), La Porta et al. (1997) and Acemoglu et al. (2001), Driffield and Jones (2013) argue that even though the institutional variables are not strongly linked to economic growth they are however strongly correlated with all three types of capital flows analysed by the author (FDI, Remittances and Aid). In addition the authors argue that investor protection, good governance and the maintenance of law and order increase the extent to which inward capital flows stimulate economic growth. The authors concluded therefore that FDI and remittances may be the trigger that generates a sizeable growth payoff. In the same vein, Djurovic (2012) found that inward FDIs were attracted to the developing nations with higher availability of educated labour, higher government spending and more efficient quality of governance. The study point to an existence of a connection between FDI and economic growth which is strengthened when other factors are included in the analysis. In line with the previous studies of North (1981), La Porta et al. (1997) and Acemoglu et al. (2001), Driffield and Jones (2013) reviewed this further shows the importance of other institutional factors when it comes to realising the positive effects of FDI.

The argument of institutions is further supported by Moura and Forte (2010). Reviewing the available studies on the impact of foreign capital on economic growth, the authors concluded that a common feature in most of the studies analysed suggest that the effects of foreign capital, specifically FDI depend on the most varied conditions existing in each country, when FDI occurs or is provided subsequently, whether they can be 
economic, political, social, cultural or other. The authors suggest that the reasons most frequently mentioned derived from the way the country can benefit from the presence of multinationals and the advantages they carry and that can be used to improve the host country's economy performance. Among these, the most mentioned is how the host country can gain by using more advanced technologies and knowledge. The review of literature has highlighted that the impact of capital flows on economic growth is not the same. FDI and remittances have featured as influencing economic growth positively; on the other hand aid presents mixed results. It is also interesting to note that the available studies in the case of the SADC region have focused much on FDI; there are no studies which have analysed the impact of the different forms of external financial flows in the region. Thus this study contributes in that context.

\section{Methodology and Theoretical Framework}

The study is underpinned by the standard endogenous growth model in which economic growth is influenced by the four forms of capital, Foreign Direct Investment (FDI), Oversees Development Assistance (ODA), Portfolio Investment (PI) and Remittances (R). Based on the work of Catrinescu et al. (2009) and Driffield and Jones (2013) it is assumed that each type of financial flow finances its own form of investment that determines economic growth. Investment is regarded as an aggregate of public and private investment, with public investment generally financed by aid in part, whilst private investment is influenced by FDI, R and FPI. The production function in this case can be stated accordingly as:

$Y_{t}=T_{t}\left(G_{t}+\varphi A_{t}+D I_{t}+F D I_{t}+\lambda R_{t}\right)^{\phi}$

Where $Y_{t}$ represents output, $G_{t}$ represents government investment spending, $A_{t}$ is ODA, $\varphi$ is share of ODA used for public investment purposes, $D I_{t}$ is domestic investment, $F D I_{t}$ is foreign direct investment which also incorporates Portfolio investment (PI), $R_{t}$ is remittances and $\lambda$ is the share of remittances devoted to private investment. Equation 4.1 was expanded to take into account Cross boarder bank flows. Thus the model becomes:

$Y_{t}=T_{t}\left(G_{t}+\varphi A_{t}+D I_{t}+F D I_{t}+\lambda R_{t}+C B F\right)^{\phi}$

In this case CBF represents Cross Boarder Bank flows. Driffield and Jones (2013) argue that Aid can influence economic growth directly or via public investment, whilst FDI and remittances influences economic growth through external private sources. The same also applies to CBF considering that it is a private source. In addition to the different forms of capital, institutional factors have emerged also as important factors determining the contribution of the forms of capital towards economic growth. Though Portfolio investment has featured as a very important source of capital as indicated in the literature review section, it is interesting to note that the majority of countries in the SADC region financial markets are still at their infancy. The stock markets are prominent but still underdeveloped. The bond market in some of the countries is non-existent. Given this, this variable was dropped in the analysis therefore. The study will therefore be based on the above framework examining four types of external finance which are FDI, CBF, ODA and remittances.

Model Specification: Based on the theoretical framework discussed in 4.1 and 4.2, the study will employ a model in which the four conventional forms of external finance are independent variables. The following equation encapsulates the estimated model:

$Y_{i}=\alpha_{i}+\sum_{i} \beta_{i} X_{i}+\varepsilon_{i}$

Where:

$Y_{i}=$ measure of economic growth for country $i$.

$\mathrm{X}_{\mathrm{i}}=$ the different forms of external finance for country $i$.

In addition to the conventional model specified above, the study will also consider other variables that determine economic growth and augments them with the different forms of external financial variables. This is important taking into account the heterogeneity of SADC countries. The review of literature has indicated that factors such as institutional quality, corruption, law and order are other variables which have been 
levelled out as other determinants of capital flows and hence economic growth. Thus the model shall incorporate these variables to come up with the following model:

$Y_{i}=\alpha_{i}+\sum_{i} \beta_{i} X_{i}+\sum_{i} \gamma_{i} Z_{i}+\varepsilon_{i}$

Where:

$Y_{i}=$ measure of economic growth for country $i$.

$X_{i}=$ Conventional explanatory variables representing the different forms of capital flows (FDI, R, ODA and

FPI) for country $i$.

$Z_{i}=$ vector of explanatory variables affecting economic efficiency such as Openness as a percentage of GDP, human capital, domestic investment, exchange rate, inflation rate, government expenditure, measure of financial development, polity.

The model can thus be written as:

$G d p_{i t}=\alpha_{i t}+\beta_{1} F D I_{i t}+\beta_{2} R E M_{i t}+\beta_{3} O D A_{i t}+\beta_{4} C B F_{i t}+\beta_{5} G F C F_{i t}+\beta_{6} M 3 / G D P_{i t}+$

$\beta_{7} B C P / G D P_{i t}+\beta_{8} P O L_{i t}+\beta_{9} O P E_{i t}+\beta_{10} G D S_{i t}+\beta_{11} I N F_{i t}+\beta_{12} E X T_{-} D B T_{i t}$

$+\beta_{13} R E M_{-} P O L_{i t}+\beta_{14} F D I_{-} P O L_{i t}+\beta_{15} O D A_{-} P O L_{i t}+\beta_{16} C B F_{-} P O L_{i t}+\beta_{17} \tau_{i t}+\beta_{18} \delta_{i t}+\varepsilon_{i t}$

The model will include two interactive dummy variables; $\tau$ and $\delta$ following the work of De Wet and Van Eyden (2005). The two authors argue that it is imperative to take into account the state of development of the South African economy when carrying out a cross-country study in which it is included. In this case $\tau$ represents the South African interactive dummy variable which will be constructed by multiplying the savings rate for each country by the South African dummy variable to take into account that South Africa has a different level of capital mobility as well as the level of savings as compared to other countries in the SADC region. De Wet and Van Eyden (2005) show that South Africa can be regarded as a 'developed' country in the context of SADC or looking at Sub-Saharan Africa. Therefore failure to take this into account would bias the rest of the region upwards. In the event that it is significant, the actual coefficient of the savings rate would be the sum of $\beta_{10}$ which represents Gross domestic savings and $\beta_{17}$. The time interactive dummy $(\delta)$ on the other hand was constructed by multiplying a time trend with the savings rate for each country. This is supported by Isaksson (2001) who argues that it captures the change in capital flows for the time period in order to evaluate the effectiveness of policy and institutional changes which are aimed at capital mobility. De Wet and Van Eyden (2005) argue that a negative value for $\beta_{18}$ will be an indication of a decrease in the savings rate, implying that policy changes are effective and capital is mobile in the region.

Estimation Techniques: The study focused on modelling the impact of the different macroeconomic and external financial variables established in the model through the simple panel modelling technique. However prior to estimating the panel technique, the properties of the data will be analysed through panel unit root tests.

Panel Unit Root tests: To obtain robust results, the study utilised several methods to carry out the unit root tests in the panels used in the study. These methods are discussed in this section.

The Levin and Lin (LL) test: This test was originally developed by Levin and Lin (1992). The test is an extension of the DF test. The model is of the following form:

$\Delta Y_{i, t}=a_{i}+\rho Y_{i, t-1}+\sum_{k=1}^{n} \phi_{k} \Delta Y_{i, t-k}+\delta_{i} t+\theta_{t}+u_{i t}$

Asteriou and Hall state that the model allow for two-way fixed effects, one coming from $a_{i}$ and the other from $\theta_{t}$. Therefore, both unit-specific fixed effects and unit specific time effects are included. The unit-specific 
fixed effects allow for heterogeneity since the lagged $Y_{i}$ is restricted to being homogenous across all units of the panel. The null and the alternative hypotheses are stated as:

$H_{0}: \rho=0$

$H_{a}: \rho<0$

The LL test also assumes that the individual processes are cross-sectionally independent implying that the pooled OLS estimator of $\rho$ will follow a standard normal distribution under the null hypothesis. However the LL test was criticised on restricting $\rho$ to be homogenous across all $i$.

The Im, Pesaran and Shin (IPS) test: Im, Pesaran and Shin (2003) extended the LL test taking into account heterogeneity on the coefficient of the $Y_{i, t-1}$ variable and proposing a procedure which relies on the average of the individual unit-root test statistics. The IPS test provides separate estimations for each $i$ section, allowing different specifications of the parametric values, the residual variance and the lag lengths. The model is given as:

$\Delta Y_{i, t}=a_{i}+\rho_{i} Y_{i, t-1}+\sum_{k=1}^{n} \phi_{i k} \Delta Y_{i, t-k}+\delta_{i} t+u_{i t}$

The null and the alternative in this case will be formulated as:

$$
H_{0}: \rho_{i}=0 \text { for all } i
$$

$H_{a}: \rho<0$ for at least one $i$

The null in this case assumes that all series are non-stationary process under the alternative that a fraction of the series in the panel are assumed to be stationary. This contradicts the LL test which assumes that all series are stationary under the alternative hypothesis.

It is also important to note that Im et al. (2003) formulated their model under the assumption that $T$ is the same for all cross-sections. This therefore requires a balanced panel in the computation of the $\bar{t}$-test statistic which is the average of the individual ADF $\bar{t}$-statistic computed as:

$\bar{t}=\frac{1}{N} \sum_{i=1}^{N} t_{\rho i}$

The authors also constructed the IPS statistic for testing for unit root in panels given by:

$t_{I P S}=\frac{\sqrt{N}\left(\bar{t}-1 / N \sum_{i=1}^{N} E\left[t_{i T} \mid \rho_{i}=0\right]\right)}{\left.\sqrt{\operatorname{Var}\left[t_{i T} \mid \rho_{i}\right.}=0\right]}$

Panel Data Estimation Methods: The impact of the different variables to be employed in the study were analysed through panel data model. The Panel data analysis has a number of advantages over the other approaches. These include its ability to increase the sample size and hence obtaining better estimates. Also Asteriou and Hall (2011) argue that under certain circumstances the problem of omitted variables which at times cause biased estimates in a single individual regression is not likely to occur. Also, Wooldridge (2002) argues that panel data controls for unobserved cross-section heterogeneity. There are three basic panel data estimation methods namely Pooled OLS, Random Effects Model (REM) and Fixed effects Model (FEM).

Pooled Regression Model: The pooled regression model emphasises the joint estimation of coefficients using the ordinary least squares (OLS) thereby increasing degrees of freedom and decreasing standard errors of the coefficients (Baltagi, 2008). Given an equation with two explanatory variables $x_{2}$ and $x_{3}$ a pooled model can be written as:

$y_{i t} \beta_{1}+\beta_{2} x_{2 i t}+\beta_{3} x_{3 i t}+e_{i t}$ 
The coefficients $\left(\beta_{1}, \beta_{2}, \beta_{3}\right.$ ) are assumed to be constant for all individual countries in all time periods, and do not allow for possible individual heterogeneity. This characteristic is what led to equation 4.10 being called a pooled model. However its major weakness is that it pools all cross-sections and time series data and estimates a common regression disregarding possible country-specific differences.

Random Effects Model: In the random effects model (REM) or the error component model (ECM), the individual effects are treated as random draws from a larger population. The random effects model can be written as:

$y_{i t}=\beta_{0}+x_{i t}^{\prime} \beta+\alpha_{i}+u_{i t}, \quad u_{i t} \sim \operatorname{IID}\left(0, \sigma_{u}^{2}\right) ; \alpha_{i} \sim \operatorname{IID}\left(0, \sigma_{\alpha}^{2}\right)$

Where $\alpha_{i}+u_{i t}$ is treated as an error term consisting of two components; an individual specific component, which does not vary over time, and a remainder component, which is assumed to be uncorrelated over time. In other words all correlation of the error terms over time is attributed to the individual effects $\alpha_{i}$. It is assumed that $\alpha_{i}$ and $u_{i t}$ are mutually independent and independent of $x_{j s}$ (for all $j$ and $s$ ). This implies that the OLS estimator for $\beta_{0}$ and $\beta$ in equation 4.10 is unbiased and consistent.

However, Gujarati $(2004,648)$ states that if the cross-section or individual-specific error component is zero there will be no difference between the pooled and the random effects model in which case one would simply run a pooled regression. Baltagi $(2008,17)$ maintains that the random effects model is appropriate if draws are made randomly from a large population where $N$ is generally large.

Fixed Effects Model (FEM): A Fixed Effects Model is a linear regression model in which the intercept terms vary over the individual countries $i$. Thus:

$y_{i t}=\alpha_{i}+x_{i t}^{\prime} \beta+u_{i t}, u_{i t} \sim \operatorname{IID}\left(0, \sigma_{u}^{2}\right)$,

Where it is usually assumed that all $x_{i t}$ are independent of all $u_{i t}$.

Gujarati and Porter (2009), states that these intercepts capture the different special features of each country. In addition, Hill et al. (2008) also states that these fixed effects can be analysed to study the extent of country heterogeneity and to examine any particular countries of interest. However, in the event that these individual effects are identical, one can then use a pooled least squares regression model. The fixed effects model can be estimated by employing the "Within" $Q$ estimation technique or the least square dummy variable (LSDV) technique. Writing equation 4.11 in a usual regression framework including a dummy variable for each unit in the model:

$y_{i t}=\sum_{j=1}^{N} \alpha_{j} d_{i j}+x_{i t}^{\prime} \beta+u_{i t}$

Where $d_{i j}=1$ if $i=j$ and 0 otherwise. There are a set of $\mathrm{N}$ dummy variables in the model. The parameters $\alpha_{1} \ldots \ldots \ldots, \alpha_{N}$ and $\beta$ in equation 4.12 can be estimated by ordinary least squares. The implied estimator for $\beta$ is referred to as the least squares dummy variable (LSDV) estimator. The estimator of $\beta$ can be obtained by performing the regression as deviations from individual means. This implies eliminating all the individual effects $\alpha_{i}$ first by transforming the data to obtain:

$y_{i t}-\overline{y_{i}}=\left(x_{i t}-\overline{x_{i}}\right)^{\prime} \beta+\left(u_{i t}-\overline{u_{i}}\right)$

Equation 4.13 does not include the individual effects $\alpha_{i}$. The transformation that produces observations in deviations from individuals means in equation 4.13 is called the within transformation. The OLS estimator for $\beta$ obtained from the transformed model is called the within estimator or fixed effects estimator and it is identical to the LSDV. It is given by: 
$\hat{\beta}_{F E}=\left(\sum_{i=1}^{N} \sum_{i}^{T}\left(x_{i t}-\bar{x}_{i}\right)\left(x_{i t}-\bar{x}_{i}\right)^{\prime}-\right)^{-1} \sum_{i=1}^{N} \sum_{t=1}^{T}\left(x_{i t}-\bar{x}\right)\left(y_{i t}-\bar{y}_{i}\right)$

Assuming that all $x_{i t}$ are independent of all $u_{i t}$, the fixed effects estimator will be unbiased for $\beta$. Both fixed effects modeling techniques namely LSDV and "WITHIN"/Q estimation methods basically produces the same results. For making inferences, the LSDV is reported as it estimates as opposed to calculating the intercept coefficients and as such produces standard errors, $t$-statistic and $p$-values.

Choosing the appropriate model: To decide between a pooled regression model (restricted) and a fixed effects model (unrestricted), the F-test was performed.

F-test: The F-test is constructed as follows:

$H_{0}: \mu_{1}=\mu_{2}=\ldots=\mu_{N-1}=0$

$H_{A}$ : Not all equal to 0

$F$ statistic $=\frac{(R S S-U R S S) /(n-1)}{U R S S /(n t-n-k)} \sim F_{(n-1),(n t-n-k)}$

Where:

$\begin{array}{lll}\text { RSS } & - & \text { Residual sum of squares from the pooled model (restricted model) } \\ \text { URSS } & - & \text { Residual sum of squares from the FEM (unrestricted model) } \\ n & - & \text { Number of cross sections (countries in the SADC region) } \\ t & - & \text { Number of time periods } \\ k & - & \text { Number of explanatory variables }\end{array}$

The F-test essentially involves a comparison of the residual sum of squares (RSS) of both models. This method is justified on the basis that OLS entails minimising the residual sum of squares. The rationale of the F-test is that if after imposing restrictions a much greater RSS is obtained then the restricted model is not supported by the data. Similarly, if the RSS decreases significantly following the restrictions then it is concluded that the restricted model is supported by the data. The null hypothesis of cross-section homogeneity is rejected if F-statistic > F-critical value at 0.05 level of significance.

The Hausman Test: The Hausman test was also carried out as a robust check to choose the appropriate technique. The general idea of the Hausman test is that two estimators are compared in which one is consistent under both the null and alternative hypothesis and one that is consistent under the null hypothesis only. A significant difference between the two estimators indicates that the null hypothesis is unlikely to hold. Assuming that $E\left\{u_{i t} x_{i s}\right\}=0$ for all $s, t$ so that the fixed effects estimator $\hat{\beta}_{F E}$ is consistent for $\beta$ irrespective of the question as to whether $x_{i t}$ and $\alpha_{i}$ are uncorrelated, while the random effects estimator $\hat{\beta}_{R E}$ is consistent and efficient only if $x_{i t}$ and $\alpha_{i}$ are not correlated.

In examining the difference between $\hat{\beta}_{F E}$ and $\hat{\beta}_{R E}$ requires estimating the covariance between the two which is:

$$
V\left\{\hat{\beta}_{F E}-\hat{\beta}_{R E}\right\}=v\left\{\hat{\beta}_{F E}\right\}-v\left\{\hat{\beta}_{R E}\right\}
$$

The Hausman test statistic will thus be computed as:

$$
\xi_{H}=\left(\hat{\beta}_{F E}-\hat{\beta}_{R E}\right)^{\prime}\left[\hat{V}\left\{\hat{\beta}_{F E}\right\}-\hat{V}\left\{\hat{\beta}_{R E}\right\}\right]^{-1}\left(\hat{\beta}_{F E}-\hat{\beta}_{R E}\right),
$$


Where the $\hat{V}$ s denotes estimates of the true covariance matrices. Under the null hypothesis, which implicitly states that $\operatorname{plim}\left(\hat{\beta}_{F E}-\hat{\beta}_{R E}\right)=0$; the statistic $\xi_{H}$ has an asymptotic Chi-squared distribution with K degrees of freedom, where $\mathrm{K}$ is the number of elements in $\beta$. The Hausman test thus will test whether the fixed effects and random effects estimators are significantly different.

\section{Results and Discussion}

As part of the analysis of the data prior to estimation, unit root tests were performed on the data to establish the level of integration of the data. The study utilised two tests, Levin and Lin (1992) and Im et al. (2003) IPS panel unit root test so as to obtain robust results thought the IPS test was considered more robust as compared to other tests as it has the ability to preserve sample properties of the data in the case of small samples. The results are reported in table 2 . However all tests indicate that the variables are stationary at level series. Having established the level of stationarity of the variables the study proceeds with the panel estimations in the next section.

Table: 2: Panel Unit Root tests

\begin{tabular}{lcc}
\hline Tests & Statistic & P-value \\
\hline Null Hypothesis: & \multicolumn{1}{c}{ Each individual series contains a unit root } \\
Im, Pesaran \& Shin (IPS) & -2.759 & $0.004^{* * *}$ \\
ADF - Fisher Chi-square & 102.2 & $0.002^{* * *}$ \\
PP - Fisher Chi-square & 87.49 & $0.037^{* *}$ \\
Null Hypothesis: & Assumes common unit root process \\
Levin, Lin \& Chu (LLC) & -5.734 & $0.000^{* * *}$ \\
$\left.* /{ }^{* *}\right] /\left(^{* * *}\right)$ denotes significance at $10 \%, /[5 \%] /(1 \%)$ level of significance respectively. \\
\hline
\end{tabular}

Source: Author's computation using Eviews 8 Econometric Software

Panel Model Estimation Results: Different tests were conducted to choose the appropriate model between the random and the fixed model. The results are reported in the appendix. The results indicate that the calculated F-statistic exceeds the F-critical value; we reject the null hypothesis that the sample of the SADC countries is homogenous. This implies that the FEM model should be utilised since it allows for country specific effects in the specification. The Husman test was also carried out to test the better model between FEM and REM, $\chi^{2}$ (Chi-Square) tests results confirmed that the FEM was the appropriate model that fit our data. The results from the FEM Model are therefore interpreted in detail. The fixed effects model takes into account the heterogeneity in the cross-section and it also assumes a different intercept for each country which is included in the sample. In this case fixed effects may represent differences in political, institutions, economic systems amongst others which are not explicitly included in the specification, which are however accounted for when estimations are carried out. The model was estimated and the results are reported in table 3.

The results indicate that all the coefficients of the different forms of external finance are positively related to economic growth in the region. The time dummy variable is positive and statistically significant in this case suggesting that changes which have occurred in the different countries have influenced the flow of capital in the different countries. This suggests also that there is a difference in the amount external finance which is attracted between South Africa and the other countries in the region. The model has an adjusted $\mathrm{R}^{2}$ which is higher than the other models. The empirical results reveal that there is a positive and significant relationship between FDI and economic growth. The coefficient of FDI is 0.22 , suggesting that a unit increase in FDI will result in economic growth increasing with about 0.22 . This is consistent with the apriori expectation as well as a number of available studies. The result in consonance with Rivera-Batiz and Romer (1991), Borensztein et al. (1998), Balasubramanyam et al. (1996), Workie (2007) and Petrakos et al. (2007). Trpkova and Tashevska (2011) argues that this is likely to arise as FDI inflows foster internationalization of production 
through the transmission of ideas that can be traded independently of goods and trade in intermediate and capital goods that embody technology, increases trade openness as well as increasing favourable spillover effects and finance external current account deficits which is a common feature in many of the SADC countries.

Table3: Fixed Effects Model Results

Dependent variable: GDP

\begin{tabular}{|c|c|c|c|c|c|}
\hline & Model 1 & Model 2 & Model 3 & Model 4 & Model 5 \\
\hline Const & $\begin{array}{l}3.3006^{* * *} \\
(0.9509)\end{array}$ & $\begin{array}{l}3.5556^{*} \\
(0.9290)\end{array}$ & $\begin{array}{l}3.5556 \\
(1.9290)\end{array}$ & $\begin{array}{l}3.1288 \\
(1.9436)\end{array}$ & $\begin{array}{l}3.9736 \\
(0.8516)\end{array}$ \\
\hline FDI & $\begin{array}{l}0.1272^{* *} \\
(0.0286)\end{array}$ & & $\begin{array}{l}0.2599 * * \\
(0.0298)\end{array}$ & $\begin{array}{l}0.2709^{* *} \\
(0.0301)\end{array}$ & \\
\hline REM & $\begin{array}{l}0.1077^{* *} \\
(0.0232)\end{array}$ & $\begin{array}{l}0.05654 \\
(0.0671)\end{array}$ & & $\begin{array}{l}0.0820^{* *} \\
(0.0166)\end{array}$ & \\
\hline ODA & $\begin{array}{l}0.1136 \\
(0.0301)\end{array}$ & $\begin{array}{l}0.0897^{*} \\
(0.0350)\end{array}$ & $\begin{array}{l}0.0935^{*} \\
(0.0346)\end{array}$ & & \\
\hline $\mathrm{CBF}$ & $\begin{array}{l}0.0888^{* *} \\
(0.0360)\end{array}$ & $\begin{array}{l}0.0827^{* *} \\
(0.0170)\end{array}$ & $\begin{array}{l}0.0544^{* *} \\
(0.0170)\end{array}$ & $\begin{array}{l}0.0779^{* *} \\
(0.0172)\end{array}$ & \\
\hline GFCF & $\begin{array}{l}0.0896 \\
(0.0214)\end{array}$ & $\begin{array}{l}0.0870^{* *} \\
(0.0354)\end{array}$ & $\begin{array}{l}0.0936 * * \\
(0.0368)\end{array}$ & $\begin{array}{l}0.1134^{* *} \\
(0.0364)\end{array}$ & $\begin{array}{l}0.0986^{* * *} \\
(0.0348)\end{array}$ \\
\hline M2/GDP & $\begin{array}{l}0.0429^{* *} \\
(0.0157)\end{array}$ & $\begin{array}{l}0.0235^{* *} \\
(0.0193)\end{array}$ & $\begin{array}{l}0.2470^{* *} \\
(0.0192)\end{array}$ & $\begin{array}{l}0.2612^{* *} \\
(0.0194)\end{array}$ & $\begin{array}{l}0.0365^{* * *} \\
(0.0182)\end{array}$ \\
\hline BCP/GDP & $\begin{array}{l}0.2413^{* *} \\
(0.0021)\end{array}$ & $\begin{array}{l}0.3210^{* *} \\
(0.0124)\end{array}$ & $\begin{array}{l}0.4210^{* *} \\
(0.0131)\end{array}$ & $\begin{array}{l}0.4012^{* *} \\
(0.0312)\end{array}$ & $\begin{array}{l}0.4123^{* * *} \\
(0.0012)\end{array}$ \\
\hline POL & $\begin{array}{l}0.0269 \\
(0.0723)\end{array}$ & $\begin{array}{l}0.2579 * * * \\
(0.0962)\end{array}$ & $\begin{array}{l}0.2585^{* *} \\
(0.0962)\end{array}$ & $\begin{array}{l}0.2935^{* *} \\
(0.0961)\end{array}$ & $\begin{array}{l}0.2883^{* * *} \\
(0.0961)\end{array}$ \\
\hline OPE & $\begin{array}{l}0.0294 \\
(0.0070)\end{array}$ & $\begin{array}{l}0.0370^{* *} \\
(0.0136)\end{array}$ & $\begin{array}{l}0.2226^{* * *} \\
(0.1365)\end{array}$ & $\begin{array}{l}0.0230^{*} \\
(0.0137)\end{array}$ & $\begin{array}{l}0.0227^{*} \\
(0.0136)\end{array}$ \\
\hline GDS & $\begin{array}{l}0.0025 \\
(0.0359)\end{array}$ & $\begin{array}{l}0.1438^{* *} \\
(0.0621)\end{array}$ & $\begin{array}{l}0.1516^{* *} \\
(0.0622)\end{array}$ & $\begin{array}{l}0.1394^{* *} \\
(0.0627)\end{array}$ & $\begin{array}{l}0.1427^{* *} \\
(0.0623)\end{array}$ \\
\hline INF & $\begin{array}{l}-0.0002 \\
(0.0001)\end{array}$ & $\begin{array}{l}-0.0002^{*} \\
(0.0001)\end{array}$ & $\begin{array}{l}-0.0002^{*} \\
(0.0001)\end{array}$ & $\begin{array}{l}0.0003^{*} \\
(0.0001)\end{array}$ & $\begin{array}{l}-0.0003^{* *} \\
(0.0001)\end{array}$ \\
\hline EXT_DBT & $\begin{array}{l}-0.0230^{* *} \\
(0.0049)\end{array}$ & $\begin{array}{l}0.0237^{* * *} \\
(0.0059)\end{array}$ & $\begin{array}{l}-0.0236^{* * *} \\
(0.0059)\end{array}$ & $\begin{array}{l}-0.0161^{* * *} \\
(0.0052)\end{array}$ & $\begin{array}{l}-0.0167^{* * *} \\
(0.0052)\end{array}$ \\
\hline REM_POL & $\begin{array}{l}0.2047^{* *} \\
(0.0902)\end{array}$ & $\begin{array}{l}0.4065^{* * *} \\
(0.0036)\end{array}$ & $\begin{array}{l}0.3010^{* *} \\
(0.0127)\end{array}$ & $\begin{array}{l}0.4121^{* *} \\
(0.0366)\end{array}$ & $\begin{array}{l}0.7503^{* *} \\
(0.2486)\end{array}$ \\
\hline FDI_POL & $\begin{array}{l}0.1505^{* *} \\
(0.0464)\end{array}$ & $\begin{array}{l}0.3431^{* *} \\
(0.0164)\end{array}$ & $\begin{array}{l}0.0659^{* *} \\
(0.0729)\end{array}$ & $\begin{array}{l}0.5868^{* *} \\
(0.1730)\end{array}$ & $\begin{array}{l}0.5311^{* * *} \\
(0.0165)\end{array}$ \\
\hline ODA_POL & $\begin{array}{l}0.1310^{* *} \\
(0.0640)\end{array}$ & $\begin{array}{l}0.0070^{*} \\
(0.0047)\end{array}$ & $\begin{array}{l}0.6745^{* *} \\
(0.0147)\end{array}$ & $\begin{array}{l}0.0749^{* *} \\
(0.0481)\end{array}$ & $\begin{array}{l}-0.0075 \\
(0.0048)\end{array}$ \\
\hline CBF_POL & $\begin{array}{l}0.0904 \\
(0.0239)\end{array}$ & $\begin{array}{l}0.0182^{* *} \\
(0.0048)\end{array}$ & $\begin{array}{l}0.0178^{* *} \\
(0.0048)\end{array}$ & $\begin{array}{l}0.0187^{* *} \\
(0.0048)\end{array}$ & $\begin{array}{l}0.5214^{* *} \\
(0.1240)\end{array}$ \\
\hline SA dummy & $\begin{array}{l}0.2191^{* *} \\
(0.0120)\end{array}$ & $\begin{array}{c}0.2290^{* *} \\
(0.0241)\end{array}$ & $\begin{array}{l}0.2141^{* *} \\
(0.0125)\end{array}$ & $\begin{array}{l}0.2345^{* *} \\
(0.0214)\end{array}$ & $\begin{array}{l}0.2145^{* *} \\
(0.0312)\end{array}$ \\
\hline Time_Dummy & $\begin{array}{l}-0.0864 \\
(0.1306)\end{array}$ & $\begin{array}{l}-0.2406 \\
(0.9461)\end{array}$ & $\begin{array}{l}-0.2425 \\
(0.9461)\end{array}$ & $\begin{array}{l}-0.5562 \\
(0.9450)\end{array}$ & $\begin{array}{l}-0.6356 \\
(0.9430)\end{array}$ \\
\hline $\mathrm{F}$ & $33.992^{* *}$ & $4.112^{* *}$ & $0.2066^{* *}$ & $3.8142^{* *}$ & $4.0150^{*}$ \\
\hline
\end{tabular}

Notes:

Standard errors reported in parentheses.

$\left.* /{ }^{* *}\right) /\left[{ }^{* * *}\right]$ indicates significance of the coefficients or rejection of the null hypothesis on a $10 \% /(5 \%) /[1 \%]$ level of significance.

Source: Author's computation using Eviews 8 Econometric Software 
The empirical results also suggest that there is a positive relationship between remittances and GDP in the SADC countries. The coefficient for remittances is 0.36 , which is relatively high. This result is consistent with Taylor (1992), Woodruff and Zenteno (2001), Giuliano and Ruiz-Arranz (2009), Adams and Cuecuecha (2010). These authors argue that remittances act as a developmental tool through their effect on investment. This is further supported by Ratha (2013) who argues that an increase in remittances apart from benefiting individuals at the household level benefits the national economy as well through increased investment. The author shows that a number of studies in Mexico have indicated that receipt of remittances is associated with greater accumulation of assets in farm equipment, higher levels of self-employment and increased smallbusiness investments in migrant-sending areas. In addition, remittances also boost domestic savings and improve financial intermediation which is a very important factor in aiding access to the financial system. A good case in point is Zimbabwe. There are a number of studies (Maphosa, 2005; Bracking \& Sachikonye, 2006; Tevera \& Chikanda, 2009) which indicates that the inflow of remittances supported development programmes in the country as the country was not able to access international funding. The ODA variable was found to be positive though economically insignificant in the base model. This is not in line with the apriori expectation, however it is supported by a number of empirical studies such as Burnside and Dollar (2004) who argues that ODA on its won it cannot influence growth in Africa. However the author argues that it becomes effective when interacted with another policy variable such as institution or a proper monetary or fiscal policy. However other studies such as Alesina and Weder (2002), Easterly et al. (2004) and Brautigam and Knack (2004) argue that there is evidence suggesting that high levels of AID is associated with deterioration in governance in Africa.

Cross Boarder banking was found to be significant and positive though the coefficient has low power. The results suggest that a unit increase in CBF will amount to about 0.09 increases in economic growth in the SADC region in the base model. This result is consistent with Macias and Massa (2009) on a study on SubSaharan Africa. The authors argue that cross boarder bank flows allows the realisation of potential benefits of financial integration which includes risk sharing, diversification and better allocation of capital among investment opportunities. In addition, cross boarder banking allows banks to take advantage of economies of scale and scope, diversify activities as well as spread risk and revenues. This will result in banks being able to improve resource allocation, risk management and improve on their profitability. Also, an increase in cross boarder bank flows augments domestic financial capacity and increases the pool of borrowing. The low impact of cross border bank flows on economic growth can be attributed to disintegration of the SADC economies. Macias and Massa show that the benefits of cross border bank flows can be realised to a greater extent if the countries concerned are integrated. However Macias and Massa (2009) argue that international banks should not control a large section of the banking sector as this would expose the banking sector to crises, for example the global financial crises of 2008 which crippled other countries banking sector. However this result is antagonistic to Durham (2003).

The four types of financial flows were interacted with institutions to examine if institutions play a role in determining their magnitude. The empirical results show that all the coefficients of the different types of external finance became more significant as compared when they are on their own. The empirical results reveal that the coefficient for FDI became 0.54 , from 0.22 . This suggests that institutional framework plays a very important role in the determination of the effectiveness of FDI flows. This is in line with Ades and Di Tella (1999), Dreher et al. (2007) and Boerner and Hainz (2009) who suggest that institutional reforms reduce investment risk, generates greater returns to the private sector investors as well as improve on innovation. At the same time institutional reform is likely to eliminate sources of corruption. Coricelli et al. (2012) also argues that the quality of institutions determine capital market efficiency in terms of property rights and in freedom from corruption. Where property rights are enforced and there are low levels of corruption, this will encourage investment, reduce transaction costs and therefore encourage FDI flows. This is further supported by Driffield and Jones (2013) who point out that where institutions fail to protect intellectual property rights of investors; this will influence the extent to which FDI will impact on growth. This occurs mainly through a reduction in the propensity of firms to invest in a country as well as impacting negatively on technology transfer as well as the extent to which investors will engage with the country's firms. 
The empirical results also suggest that the magnitude of remittances becomes more pronounced when it is interacted with institutions. This again stresses the importance of institutions in determining the extent to which remittances impact on economic growth. This is supported by a number of studies such as Catrinescu et al. (2009). The authors argue that good institutions are important to encourage people to remit to their countries. In a situation where institutions are not in order, for example the case of an informal economy, there is likely to be high transaction costs. Also in such instances there maybe theft of remittances. In such cases their effect on economic growth will be reduced. The results thus suggest that SADC countries should improve on their institutional frameworks so as to realise the benefits of remittances. The effect of AID on the other hand when interacted with institutions becomes significant suggesting that good institutions are a prerequisite for the effectiveness of aid. This is consistent with Burnside and Dollar (2004) who established that aid on its own has no effect on growth; however when it is interacted with institutions it will have a conditional effect. This is also consistent with Burnside and Dollar (2004), Chauvet and Guillaumont (2004). However cross boarder bank flows become more significant when interacted with institutions. This again supports the importance of institutions in determining the effectiveness of external finance. The positive impact of foreign capital on economic growth suggest that this is another channel through which a crisis in developed countries may be transmitted to the SADC region as a reduction in foreign capital will negatively impact the growth prospects of SADC countries.

The measure of institutional quality on its own was found to have a positive relationship with growth. This is supported by Acemoglu et al. (2001) and Rodrik (2004). The results suggest that institutions are of great importance to the success of the economies in the SADC region. Driffield and Jones (2013) argue that institutions act as the bedrock of a successful functioning mixed economy as markets are embedded in the institutions. The role of institutions as indicated earlier on impacts also on other important determinants of economic growth. Thus it becomes important to always maintain quality institutions. Another important finding in the study is the negative value of the time interactive dummy which was negative in all the estimations suggesting that institutional changes and policies aimed at attracting external finance has been successful. In addition to the different types of financial flows examined in the study, a number of macroeconomic variables were also examined which include inflation, openness, financial development, Gross fixed capital formation, institutional quality, and domestic savings. All these macroeconomic variables have proved to have a positive impact on economic growth in the SADC region.

\section{Conclusion and Policy Implications of the Study}

The study focused on analysing the impact of the different forms of external financial flows on economic growth in the SADC region emphasising the importance of institutions utilising a panel model. The analysis in the study highlights that the importance of external financial flows to countries in the SADC region cannot be underestimated given that countries have low levels of savings to finance investment. Thus the gap between savings and investment can only be filled in with external financial flows. The empirical results revealed that three types of external finance, FDI, CBF and remittances have a positive impact on economic growth in the region. On the other hand ODA was found to be insignificant. However when all the types of external financial flow were interacted with the measure of institutions, they all became significant including ODA. For the other three types of financial flows the impact was more significant stressing the important role played by institutions in enhancing growth in the region. The empirical results strongly suggest that policies targeted at enhancing the flow of the different forms of financial flows (especially FDI, Remittances and Cross Border bank flows) should be adopted in the region. Attention should also be paid on how macroeconomic policies can be designed with the aim of bolstering domestic productivity and improving institutional infrastructure so as to promote economic growth as a way of stimulating the inflow of foreign direct investment, Cross border bank flows and ODA. There is also need to diversify the economic base so as to establish other avenue which can support economic growth in addition to foreign capital flows.

Countries in the region should also pursue the objective of financial integration in the region. This will enable countries to benefit from cross-border bank flows as it increases opportunities for risk sharing and diversification as well as better allocation of capital amongst investment opportunities. However, there is need to also consider the potential vulnerability which can emanate from such an arrangement as it exposes the banking system to crises through opening transmission channels of systemic risk across borders. 
However, reinforcing the regulatory and supervisory framework can mitigate this. The growth regression results have strongly indicated that the quality of institutions matter most for growth in the SADC region. Apart from improved institutional quality attracting foreign financial flows, it also has a positive impact on growth. This shows the importance of the institutional variables in promoting growth in the region. Countries where there is no investor protection and maintenance of law and order are likely to lose out on attracting financial flows. This will retard economic growth. A good case is Zimbabwe which based on its law of indigenisation, there has been capital flight coupled with a shrunk in GDP. The results also imply that the foreign financial flow is another channel through which crises in developed countries can be spread to developing countries through a reduction in finance. This suggests the need to focus on policies aimed at mobilising domestic resources if a country is to achieve sustainable economic growth in the long-run. The initiative of regional integration in the region should be pursued as it has the potential of increasing cross border bank flows.

\section{References}

Acemoglu, D., Johnson, S. \& Robinson, A. (2001). The colonial origins of comparative development: An empirical investigation. American Economic Review, 91(5), 1369-1401.

Adams Jr, R. H. \& Cuecuecha, A. (2010). Remittances, household expenditure and investment in Guatemala. World Development, 38(11), 1626-1641.

Adams, S. (2009). Can foreign direct investment (FDI) help to promote growth in Africa? African Journal of Business Management, 3(5), 178-183, May 2009.

Ades, A. \& Di-Tella, R. (1999). Rents, competition and corruption. American Economic Review, 89(4), 982-993.

Agrawal, G. \& Khan, A. (2011). Impact on FDI on GDP: A Comparative Study of China and India. International Journal of Business and Management, 6(10), 71-79.

Alesina, A. \& Weder, B. (2002). Do corrupt governments receive less foreign aid? American Economic Review, 92(4), 1126-1137.

Asteriou, S. G. \& Hall, D. (2011). Applied Econometrics, A modern approach using Eviews and Microfit (Revised edition).Palgrave Macmillan.

Atique, Z., Ahmad, M. H. \&Azhar, U. (2004). The impact of FDI on economic growth under foreign trade regimes: A case study of Pakistan. The Pakistan Development Review, 43(4), 707-718.

Ayanwale, A. B. (2007). FDI and Economic Growth: Evidence from Nigeria, African Economic Research Consortium Research Paper No. 165, 2007.

Balasubramanyam, V. N., Salisu, M. \& Sapsford, D. (1996). Foreign direct investment and growth in EP and IS countries. The Economic Journal, 106(434), 92-105.

Baltagi, B. H. (2008). Econometrics, $4^{\text {th }}$ Edition, Springer-Verlag Berlin Heidelberg

Boerner, K. \& Hainz, C. (2009). The political economy of corruption and the role of economic opportunities. Economics of Transition, 17(2), 213-240.

Borensztein, E., De Gregorio, J. \& Lee, J. W. (1998). How does foreign direct investment affect economic growth? Journal of International Economics, 45(1), 115-135.

Bracking, S. \& Sachikonye, L. (2006). Remittances, poverty reduction and the in formalisation of household wellbeing in Zimbabwe, Economic \& Social Research Council, GPRG-WPS-045.

Brautigam, D. \& Knack, S. (2004). Foreign aid, institutions, and governance in Sub-Saharan Africa. Economic Development and Cultural Change, 52(2), 255-285.

Burnside, C. \& Dollar, D. (2004), Aid, policies, and growth: Reply. American Economic Business Management, 3(5), 178-183, May 2009.

Cali, M., Massa, I. \& Willem-teVelde, D. (2008). The Global Financial Crisis: financial flows to developing countries set to fall by one quarter, Oversees Development Institute.

Carkovic, M. \& Levine, R. (2002). Does Foreign Direct Investment Accelerate Economic Growth? In H. T. Moran, E. Graham and M. Blomstrom (eds.), Does FDI Promote Development? Washington, DC: Institute for International Economics.

Catrinescu, N., Leon-Ledesma, M., Piracha, M. \& Quillin, B. (2009). Remittances, institutions, and economic growth. World Development, 37(1), 81-92.

Chauvet, L. \& Guillaumont, P. (2004). Aid and Growth Revisited: Policy, Economic Vulnerability and Political Instability. In B. Tungodden, N. Stern, I. Kolstad (eds).Towards Pro-Poor Policies - Aid, Institutions and Globalization. World Bank/Oxford University Press. 
Choong, C., Ahmad, Z. B., Zulkornain, Y. \& Habibullah, M. S. (2010). Private capital flows, stock market and Commission on Growth and Development, Working Paper N.34.

Coricelli, F., Driffield, N. L., Roland, I. \& Pal, S. (2012). When does leverage hurt productivity growth? A firm level analysis. Journal of international Money and Finance, 31(6), 1674-1694.

De-Wet, A. H. \& Van-Eyden, R. (2005). Capital Mobility in Sub-Saharan Africa: A Panel data Approach. South African Journal of Economics, 73(1). 22 - 35.

Djurovic, A. (2012). The Impact of Foreign Direct Investment on the Economic Growth of Developing Countries (2000-2010) (October 10, 2011). Economic Development, 2-3, 160-175.

Dreher, A., Kotsogiannis, C. \& McCorriston, S. (2007). Corruption around the world: Evidence from a structural model. Journal of Comparative Economics, 35(3), 443-466.

Driffield, N. \& Jones, C. (2013). Impact of FDI, ODA and Migrant Remittances on Economic Growth in Developing Countries: A System Approach. European Journal of Development Research, 25(2), 173 196.

Duasa, J. \& Kassim, S. H. (2009). Foreign portfolio investment and economic growth in Malaysia. The Pakistan Development Review, 48(2), 109-123.

Durham, J. B. (2003). Foreign Portfolio Investment, Foreign Bank Lending, and Economic Growth. DynReg Working Papers, available at http://www.esri.ie/research/current_research_projects/dynreg/papers.

Easterly, W., Levine, R. \& Roodman, D. (2004). Aid, policies, and growth: Comment. American Economic Review, 94(3), 774-780.

Economic Commission for Africa. (2009). Economic Report on Africa 2009; Developing African Agriculture

Through Regional Value Chains; United Nations Economic Commission for Africa, Addis Ababa, Ethiopia.

Ekanayake, E. M. \& Chatrna, D. (2010). The effect of foreign aid on economic growth in developing countries. Journal of International Business and Cultural Studies, 3(2), 1-13.

Giuliano, P. \& Ruiz-Arranz, M. (2009). Remittances, financial development, and growth. Journal of Development Economics, 90(1), 144-152.

Griffin, K. (1970). Foreign Capital, Domestic saving and Economic Development. Bulletin of Oxford University Institute of Economics and Statistics, 32, 99 - 112.

Gujarati, D. N. (2004). Basic Econometrics (Fourth Ed), McGraw-Hill/Irwin, New York (2004).

Gujarati, D. N. \& Porter, D. C. (2009). Basic econometrics (5 ${ }^{\text {th }}$ Ed.). Boston: McGraw-Hill.

Hill, C. R., Griffiths, W. E. \& Lim, G. C. (2008). Principles of Econometrics, 4th Edition, Wiley

Im, K., Pesaran, M. H. \& Shin, Y. (2003). Testing for Unit Roots in Heterogeneous Panels. Journal of Econometrics, 115, 53-74.

Isaksson, A. (2001). Financial Liberalization, Foreign Aid, and Capital Mobility: Evidence from 90 Developing Countries. Journal of International Financial Markets, Institution, and Money, 11, 309-338.

Khaliq, A. \& Noy, I. (2007). Foreign Direct Investment and Economic Growth: Empirical Evidence from Sectoral Data in Indonesia, Working Papers 200726, University of Hawaii at Manoa, Department of Economics.

La Porta, R., Lopez-de-Silanes, F., Shleifer, A. \& Vishny, R. W. (1997). Legal determinants of external finance. Journal of Finance, 52(3), 1131-1150.

Levin, A. \& Lin, C. F. (1992). Unit root tests in panel data: asymptotic and finite-sample properties. UC San Diego, Working Paper 92-23.

Macias, J. B. \& Massa, I. (2009). The Global Financial crisis and Sub-Saharan Africa; The effects of slowing private capital inflows on growth, Overseas Development Institute, Working Paper 304.

Maphosa, F. (2005). The Impact of Remittances from Zimbabweans Working in South Africa on Rural Livelihoods in the Southern districts of Zimbabwe, Forced Migration Working Paper Series \#14 Forced Migration Studies Programme, University of the Witwatersrand [online] http://migration.wits.ac.za (accessed 15 September 2012).

Moura. \& Forte, R. (2010). The Effects of Foreign Direct Investment on the Host Country Economic Growth Theory and Empirical Evidence, FEP Working Papers 390, Universidade do Porto, Faculdade de Economia do Porto.

Muradzikwa, S. (2002). Foreign Investment in SADC, Development Policy Research Unit Working Paper $02 / 67$.

North, D. (1981). Structure and Change in Economic History. Norton. 
Obstfeld, M. (2008). International Finance and Growth in Developing Countries: What Have We learned? Commission on Growth and Development, Working Paper N.34.

Papaioannou, E. (2005). What drives International Bank Flows? Politics, Institutions and Other Determinants, European Central Bank, Working Paper Series, No. 437/ February 2005.

Petrakos, G., Arvanitidis, P. \& Pavleas, S. (2007). Determinants of Economic Growth: The Experts' View, Policy Brief No. 51.South Africa Southern African Migration Project Resources.[Online], Available on <http://www.queensu.ca/samp/sampresources/samppublications/policyseries/Acrobat51.pdf>.

Prasad, E., Rajan, R. \& Subramanian, A. (2007). The Paradox of Capital. Finance and Development, 44(1). private capital inflows on growth, Overseas Development Institute, Working Paper 304.

Rachdi, H. \& Saidi, H. (2011). The Impact of Foreign Direct Investment and Portfolio Investment on Economic

Rana, P. B. \& Dawiling, J. M. (1990). Foreign Capital and Asia economic Growth. Journal of Asian Development, $8(1)$.

Ratha, D. (2013). The Impact of Remittances on Economic Growth and Poverty Reduction. Migration Policy Institute, Washington, D.C.

Reisen, H. \& Soto, M. (2001). Which Types of Capital Inflows Foster Developing-Country Growth? International Finance, 4(1), 1-14.

Rivera-Batiz, L. A. \& Romer, P. M. (1991). International Trade with Endogenous Technological Change, NBER Working Papers 3594, National Bureau of Economic Research, Inc.

Rodrik, D. (2004). Getting Institutions Right. CESifo DICE Report, 2(2), 10-15.

Schoenmaker, D. \& Wagner, W. (2011). The Impact of Cross-Border Banking on Financial Stability. Duisenberg School of Finance-Tinbergen Institute Discussion paper, TI 11-054/DSF 18.

Southern Africa Development Community. (2009), Update on the Impact of the Global Economic Crisis on SADC. TIFI Directorate April 2009.

Southern African Development Community. (2013). SADC \& Figures, [Online], Available on < http://www.sadc.int/about-sadc/overview/sadc-facts-figures/>, Accessed on 20 September 2013.

Taylor, J. E. (1992). Remittances and inequality reconsidered: Direct, indirect, and intertemporal effects. Journal of Policy Modeling, 14(2), 187-208.

Tevera, D. \& Chikanda, A. (2009). Migrant Remittances and Household Survival in Zimbabwe, Migration Policy Brief No. 51.South Africa Southern African Migration Project Resources.[Online], Available on <http://www.queensu.ca/samp/sampresources/samppublications/policyseries/Acrobat51.pdf>.

Toulaboe, D., Terry, R. \& Johansen, T. (2009). Foreign direct investment and economic growth in developing countries. $\quad$ Retrieved from http://www.ser.tcu.edu/2009/SER2009\%20Toulaboe\%20et\%20al\%20155-170.pdf

Trpkova, M. \& Tashevska, B. (2011). Determinants of Economic Growth in South-East Europe: a Panel Data Approach. Perspectives of Innovations in Economics and Business, 7(1), 12-15.

Waheed, A. (2004). Foreign Capital Inflow and Economic Growth of Developing Countries: A critical survey of selected empirical studies. Journal of Economic Corporation, 25(1), 1-36.

Weeks, J. (2012). Macroeconomic Impact of Capital Flows in Sub-Saharan Countries, 1980-2008, Political Economy Research Institute, Working Paper Series Number 290.

Woodruff, C. M. \& Zenteno, R. (2001). Remittances and Microenterprises in Mexico. UCSD, Graduate School of International Relations and Pacific Studies Working Paper.

Wooldridge, J. M. (2002). Econometric Analysis of Cross Section and Panel Data, The MIT Press. Cambridge, Massachusetts. London, England.

Workie, T. M. (2007). Does financial development enhance economic growth? An empirical exploration. In: Currency, Banking and Financial Markets: International conference proceedings: 27th-28th September 2007 Somnolence. Bratislava: Faculty of Economics, Economic University in Bratislava, 2007.

World Bank (2012). World Development Indicators April 2004. Washington: The World Bank. 


\section{APPENDIX}

\section{Sample Countries}

Angola

Botswana

Democratic Republic of the Congo

Lesotho

Madagascar

Malawi

Mauritius

Mozambique

Namibia

Seychelles

South Africa

Swaziland

Tanzania

Zambia

Zimbabwe

\section{Testing for the Best Model}

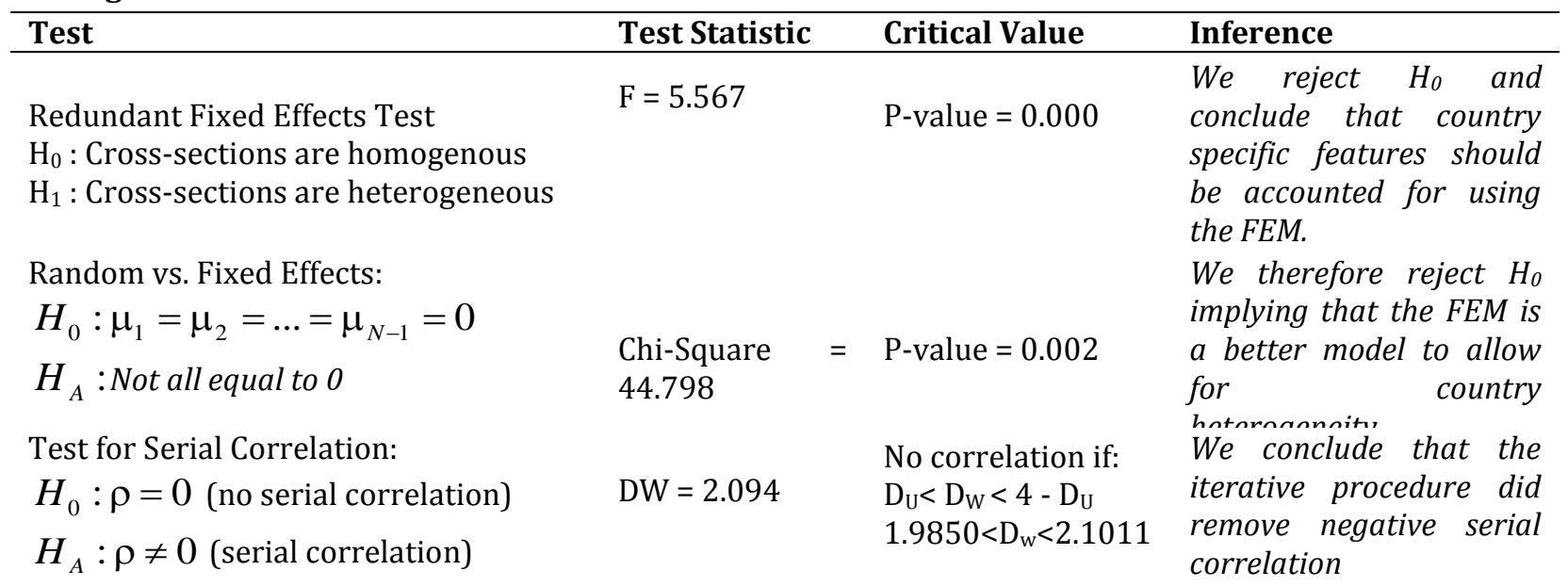

Heteroscedasticity:

$H_{0}: \sigma_{i}^{2}=\sigma$ (homoscedastic errors)

White diagonal standard errors and covariances were used to $H_{A}$ :Not equal for all $i$ correct the problem of heteroscedasticity.

(heteroscedastic errors) 